\title{
Initial phases in reef development, studied at artificial reef types off Eilat, (Red Sea)*
}

\author{
H. SCHUHMACHER \\ Ruhr-Universität Bochum, Lebrstubl für Spezielle Zoologie; \\ Bochum, Federal Republic of Germany
}

\begin{abstract}
The initial steps in the formation of a coral reef (as distinct from the enlarging of an already existing reef) have been observed at block moles off Eilat (Red Sea). Within a period of 11 years, thus far four phases can be distinguished: (1) start-phase: rapid and homogeneous colonization by fouling organisms, still indeterminant for the final reef development; (2) preparation-phase: settling of shells, calcareous red algae and foraminiferans not affected by grazing animals which largely consume the initial settlers and subsequently attaching larvae; (3) phase of pioneer frame-building: growth of scleractinians and hydrocorals, settled on the remains of rock-attached shells or on other places inaccessible to grazers; secondary frame-builders (e.g. Tridacna) grow in their shelter; (4) phase of frame-binding: dead coral colonies are overgrown by calcareous foraminiferans, algae and bryozoans consolidating the coralline structures by their deposits. Living corals are successively colonized by a specific community (mainly decapods and molluscs); among these, borers are the earliest settlers. Upon death of the coral, there is a complete change in associated organisms forming a less specific but more diverse community.
\end{abstract}

\section{INTRODUCTION}

The term "coral reef" implies a solid, three dimensional structure rising from the seabed towards the surface as well as an assemblage of organisms forming a specific, highly diverse community. Whereas the geologist is concerned with the first aspect, the biologist focuses his attention to the latter one concentrating on living organisms. The ecologist, however, must consider b oth aspects realizing the permanent interactions between reef structure and reef organisms: Organisms deposit and transform the reef substance to mould the habitat they utilize.

In recent times there have been very few occasions where the formation of this complex ecosystem has been observed. Where the environment is suitable, living reefs already exist. The flourishing reefs offer superficial impressions, but their complexity defies analytical insight. Grigg \& Maragos (1974) had the rare opportunity to trace the development from a barren virgin substrate to a coral reef on submerged lava flows off Hawaii. In the present case, artificial embankments near Eilat (Gulf of

\footnotetext{
* Supported by the Deutsche Forschungsgemeinschaft.
} 
Aqaba, Red Sea) provide a unique possibility to study step by step the increasing complexity, from the settling of the first invaders onward.

The development of the coral reef ecosystem from the first coral nucleus onward takes decades or centuries. Hence the observations off Eilat covering a total of 11 years represent only the initial stages in reef formation. The longevity of this community usually masks the dynamics of the developmental processes. On the other hand, this extended process makes it possible to study simultaneously abiotic and biotic parameters, including behaviour and adaptations of colonizing organisms, successional events and the increasing complexity of the total system. Furthermore, it allows us to analyse the forces which preserve or break down the calcareous framework; finally, one may measure the increase in diversity and substance.

\section{OBSERVATION PERIOD, LOCATION AND METHODS}

The studies reported began at the end of 1969 and continued until March, 1971; thereafter, sporadic observations were taken until March, 1976. The sites of the observations were the breakwaters of the yacht harbour (YH) and the glassbottomed boat harbour (GBH) at Eilat, as well as parts of the embankment along the coastal road from Eilat to southern Sinai (Fig. 1). At the beginning of my observations, the block moles along the road were just emplaced. The new mole of the GBH was half a year old; the old mole, four years, when the studies began. Details of colonization on pillars of the merchant harbour have been considered elsewhere (Schuhmacher, 1973).

The total length of the harbour moles and the studied part of the road embankment is ca. $450 \mathrm{~m}$. The length of the sea walls and their various exposures to insolation, wind, currents, sedimentation, temperature regimes and sea swell offer excellent opportunities for discerning the interaction of combinations of these factors. The moles, constructed of polygonal granite boulders of between 50 and $120 \mathrm{~cm}$ in diameter, slope down to depths of 1 to $7 \mathrm{~m}$ (Fig. 2c). They represent a system of holes and projections exposed to abiotic and biotic influences like a natural reef. Further description, especially concerning the environmental details of the moles, can be found in a previous paper (Schuhmacher, 1974).

In addition, asbestos panels of different size and in various configurations (Fig. $2 a, b)$ were set out near the harbour moles and exposed for periods ranging from 1 month to 6 years. Mapping, measurements and collections were done along representative transects by periodic skin- and scuba-diving. The zoological material collected was identified by many specialists whose assistance is sincerely acknowledged. In the laboratory, SEM and various geological techniques were used to elucidate the calcareous infrastructure.

\section{RESULTS}

A synopsis of the observations from the differently aged reef types yields the following outlines of succession in reef development (Fig. 7). In spring time, two 


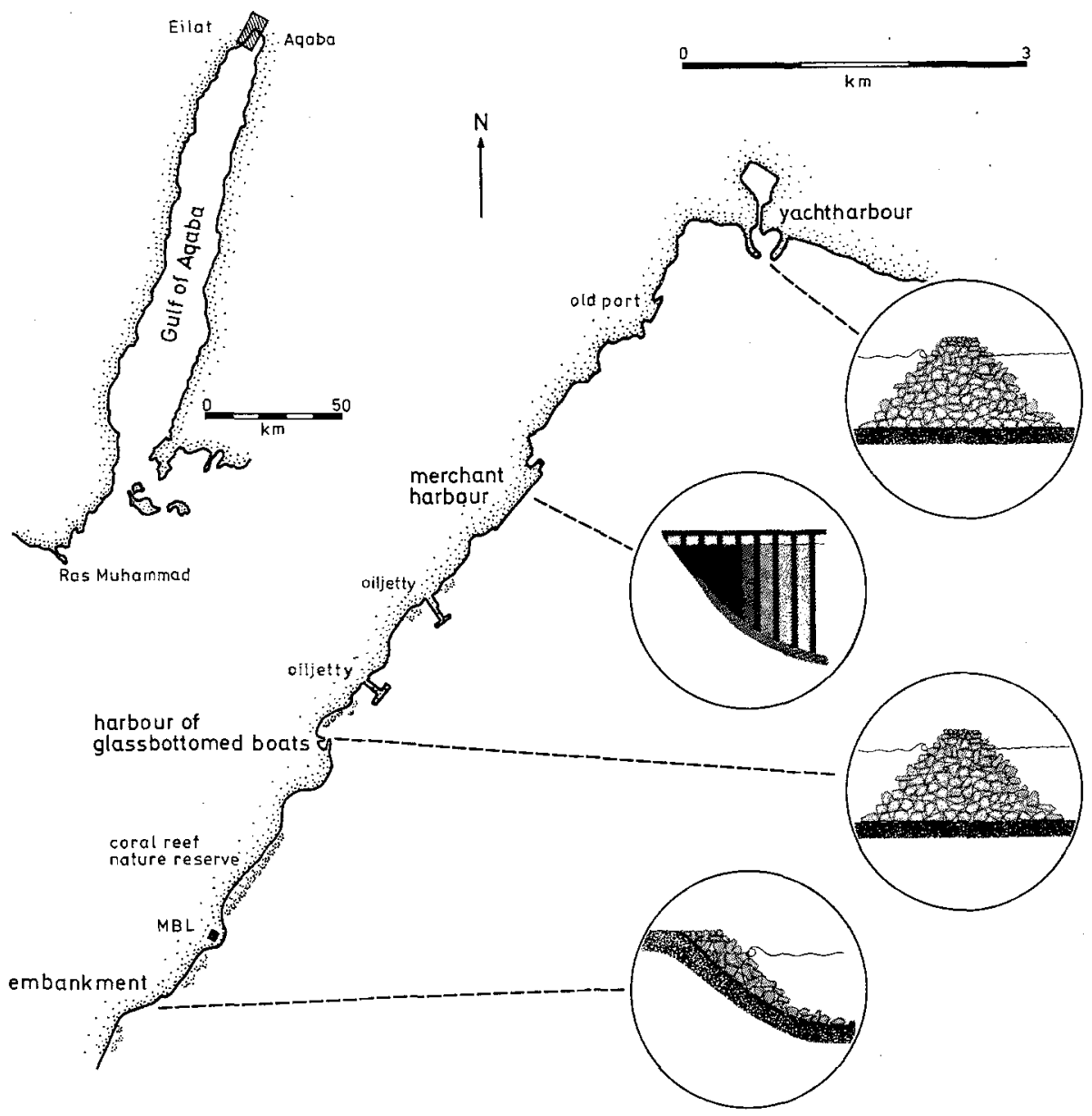

Fig. 1: Location of investigated sites; encircled symbols indicate type of artificial reef structures (MBL: Marine Biology Laboratory)

weeks after their establishment, the solid substrata were covered by thin veils of long filamentous algae (Enteromorpha clatbrata elongata). During summer and autumn, however, slimy layers of diatoms (Melosira spp.) occupied the recently emplaced rocks (Fig. 3a). They vanished after 2 to 3 months. After 4 to 6 weeks barnacles (Tetraclita squamosa rufotincta) settled in the surf exposed area. Whereas various calcareous tubeworms (e.g. Filograna implexa) and bryozoans already settled on the colonization plates exposed to open water, these animals were rare among the first invaders on the block moles. Several Spirorbis species belonged to the pioneers on the boulders. After 3 months, short filamentous green, brown and red algae began to carpet the substratum trapping fine silt and detritus and thus providing a pasture for grazing animals such as prosobranchs, sea urchins, and sea cucumbers. 

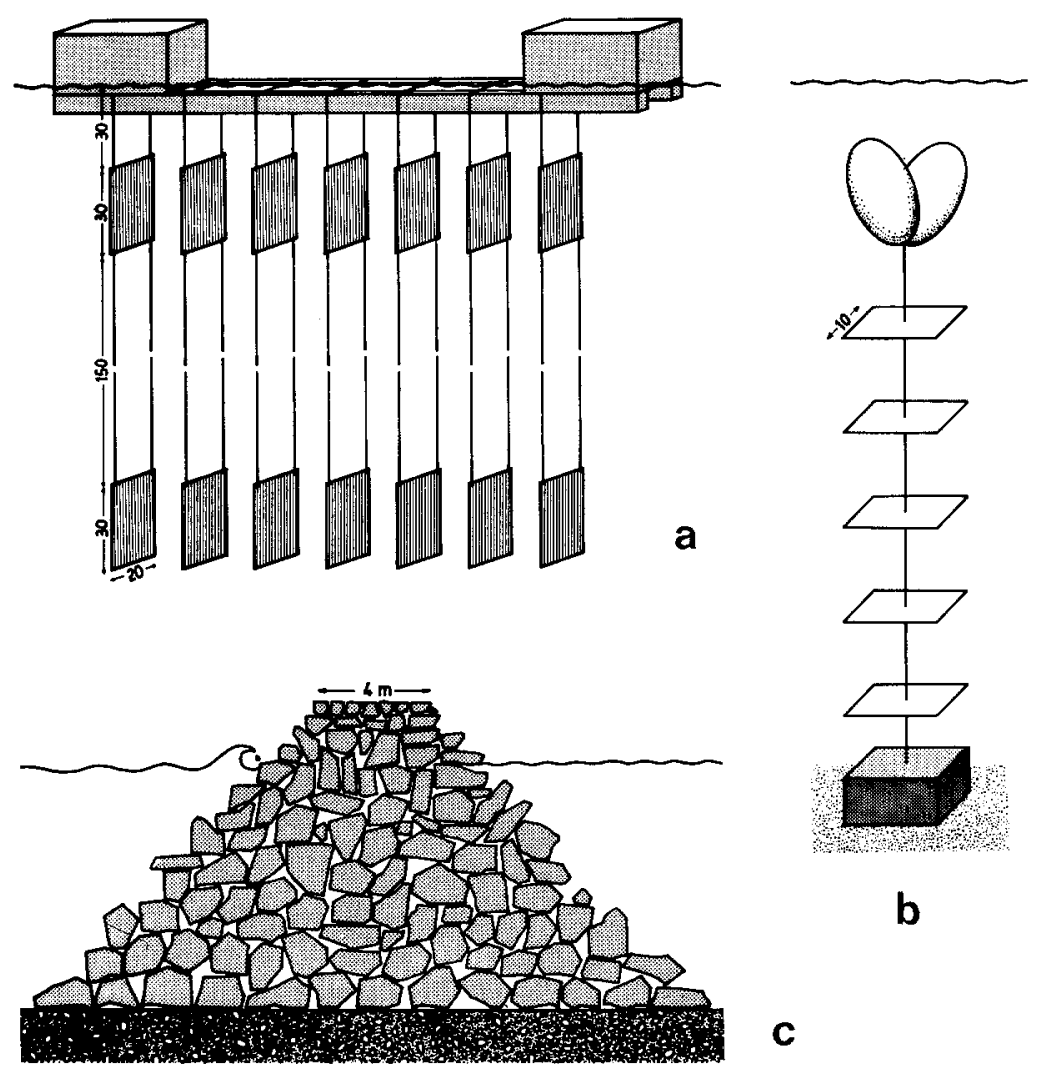

Fig. 2: Types of colonization-substrata used: a pairs of vertical asbestos plates hanging below a raft at 30 or $210 \mathrm{~cm}$ below surface (dimensions of set and plates in accordance with OECD standard 1966, measures in $\mathrm{cm}$ ); $b$ set of horizontal plates kept afloat by buoys; $c$ diagrammatic cross-section through a harbour mole of big boulders

After half a year, the shells of vermetids (Serpulorbis inopertus), various oysters (Hyotissa byotis, Lopha folium, Saccostrea cucullata), at least two Chama species and Spondylus gaederopus had attached to the granite boulders (Fig. 3b). Most of these shells had a life span of only one or few years; thereafter, the remaining halves attached to the rock provided a preferred substratum for corals. Foraminiferans and some calcareous algae (e.g. Fosliella sp.) formed coin-sized layers, conspicuous after half a year following the establishment of the moles. The calcareous alga Porolithon sp. was restricted solely to surf-exposed areas.

The hydrocorals Millepora exaesa, $M$. dichotoma and stony corals (Stylophora pistillata, Pocillopora danae, Cyphastrea microphthalma, Favia favus, F. laxa, Porites sp.) were first noticed one year after boulder establishment. They exhibited preference to limestone substratum, including pieces of coral flagstone (which were among the mole boulders), the afore-mentioned half shells (Fig. $3 \mathrm{~d}$ ), or the calcareous layers deposited by algae or foraminiferans (Fig. 3e). Eighty $\%$ of the corals settled on 
ridges, in small crevices (Fig. 3c) or on the vertical sides of the boulders. Besides some local influence of heavy sedimentation, the grazing sea urchins (the day-active Tripneustes gratilla and the night-active Diadema setosum) were found to limit the corals from most of the horizontal or gently sloped planes of the rocks (Schuhmacher, 1974).

Individual coral colonies harbour a $\mathrm{specific} \mathrm{micro-com} \mathrm{munity}$. The following common species made their first appearance: Coral crabs (Trapezia cymodoce and - less common - T. ferruginea, T. guttata, T. rufopunctata and Tetralia glaberrima) were found in 2-year or older Stylophora colonies. These crabs were young and had a carapax width of ca. $5 \mathrm{~mm}$. Juveniles of the coral shrimps Alpheus sublucanus and Harpiliopsis depressus occurred in 1- to 2-year old Stylophora or Pocillopora colonies which were at least double branched.

A conspicuous coral commensal is the gall-forming crab Hapalocarcinus marsupialis. The females induce Stylophora, Pocillopora and Seriatopora colonies to branch abnormally and to form a pocket- or basket-like gall around the crab (Potts, 1915). The earliest symptoms were recorded at colonies 4 to 5 years old. There is evidence that the final formation of the gall is completed within half a year. The related crab Cryptochirus coralliodytes penetrated spherically growing corals as Platygyra lamellina or Favia spp. both at least 2 to 3 years old. It takes approximately the same time for the tubeworm Spirobranchus giganteus to become established on a coral. The snail Quoyula madreporarum, a parasite, feeds directly upon tissue of the corals Pocillopora or Stylophora. They were found on corals 4 to 5 years old.

B oring orga $\mathrm{n}$ is $\mathrm{ms}$ invaded corals very early; 11 individuals of Lithophaga sp. of 3 to $5 \mathrm{~mm}$ length were found in a $5 \mathrm{~mm}$ thick and 18 months old Montipora crust (Loya already found the shells in Stylophora colonies less than 1 year old, personal communication). Branches of Stylophora colonies, 3 years old, were regularly infested by Lithophaga cumingiana and L. hanleyana which especially weakened the forkings of the skeleton. Boring sponges, however, were found only after the colonies attained an age of 4 years. In order for Cliona and related sponges to invade living corals, the coralline tissue must be partially damaged. Such damage typically occurs around the openings of the Lithophaga burrows.

Fig. 3: Aspects of community development on artificial reef types: a start phase - slimy diatom layers (Melosira sp.) on recently established boulders (road embankment); $b$ preparation phase - Serpulorbis inopertus and numerous Chama specimens (GBH); $c$ phase of pioneer frame building - Stylophora pistillata individuals 1 and 2 years old in a rock crevice; each square measures $10 \times 10 \mathrm{~cm}(\mathrm{GBH}) ; d$ phase of pioneer frame building - Stylophora colonies (6 to 7 years old attached to old Chama shells; frame measures $50 \times 50 \mathrm{~cm}(\mathrm{GBH})$; $e$ phase of pioneer frame building - section of an overgrown granite piece: encrusting foraminiferans developed of fissure in several layers (between arrows), later, they were completely covered by a colony of Leptastrea purpurea (YH); $f$ phase of secondary frame building colony of Stylophora pistillata with two individuals of Tridacna maxima on the edge of a boulder (GBH); $g$ phase of framework binding - colony of Pocillopora danae which, after a life span of 6 years, has been encrusted mainly by foraminiferans and calcareous algae during an additional 2 years, the scale bar represents $3 \mathrm{~cm}(\mathrm{YH}) ; b$ phase of framework binding the left specimen represents a mazerated branch of Pocillopora danae compared with (right) a typical branch from the colony in $g$ coated by foraminiferans; note increment of calcareous matter by subsequent encrustations 

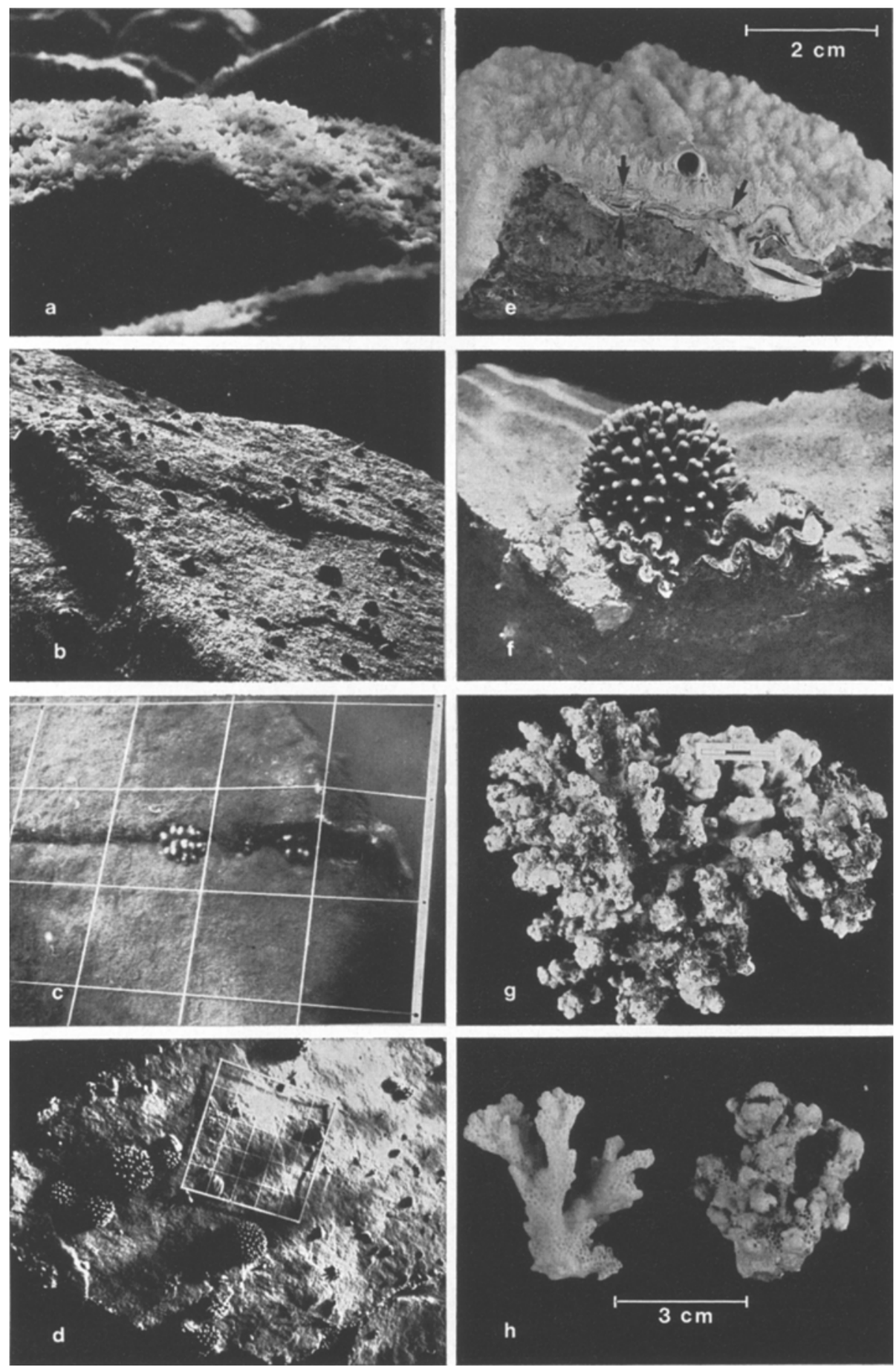
The community around a pioneer coral colony continues to evolve by $\mathrm{g} \mathrm{r}$ o u p in $\mathrm{g}$ of additional scleractinian corals, shells, ascidians and other sessile organisms in close neighbourhood. For example, the dominant part of Tridacna individuals on the moles is found closely fixed to corals (Fig. 3f, 4).

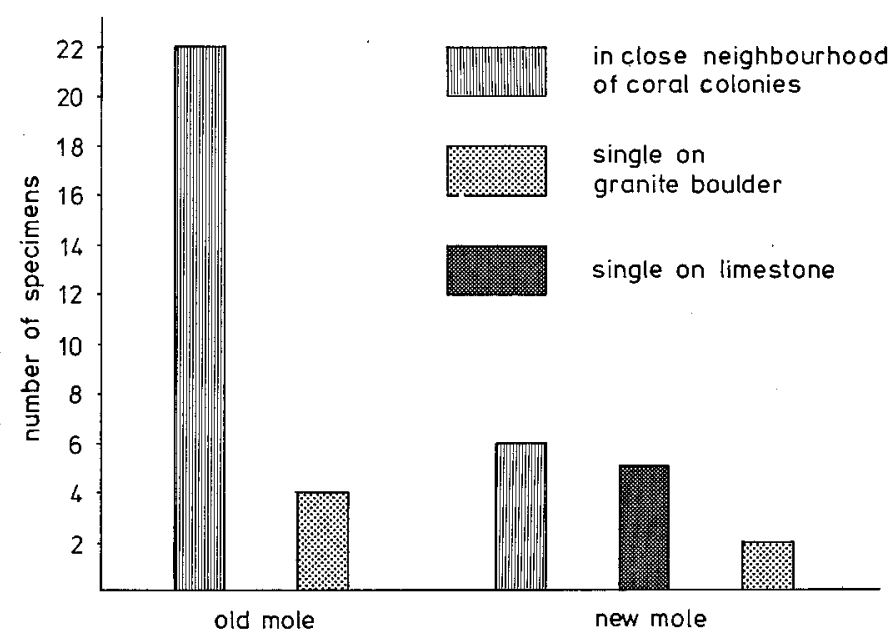

Fig. 4: Occurrence of Tridacna on the moles of the GBH (new mole contains two boulders of rugged coral limestone being much more attractive to reef benthos than granite boulders)

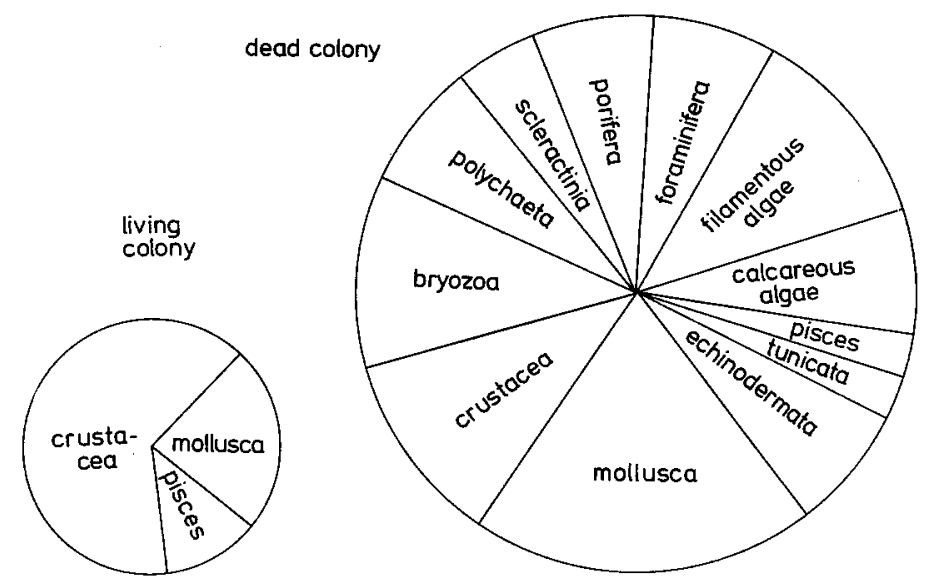

Fig. 5: Comparison between a community on a live colony of Pocillopora danae and a dead one of approximately the same size (both ca. 6 years old); the differently-sized circles represent a total of 8 or 42 macroscopic species

There is a considerable mortality of young coral colonies: Thirty $\%$ of the age group 5 to 7 years died, thus providing a substratum for successive settlers. Younger corals exhibited an even higher mortality, but their remains were generally 

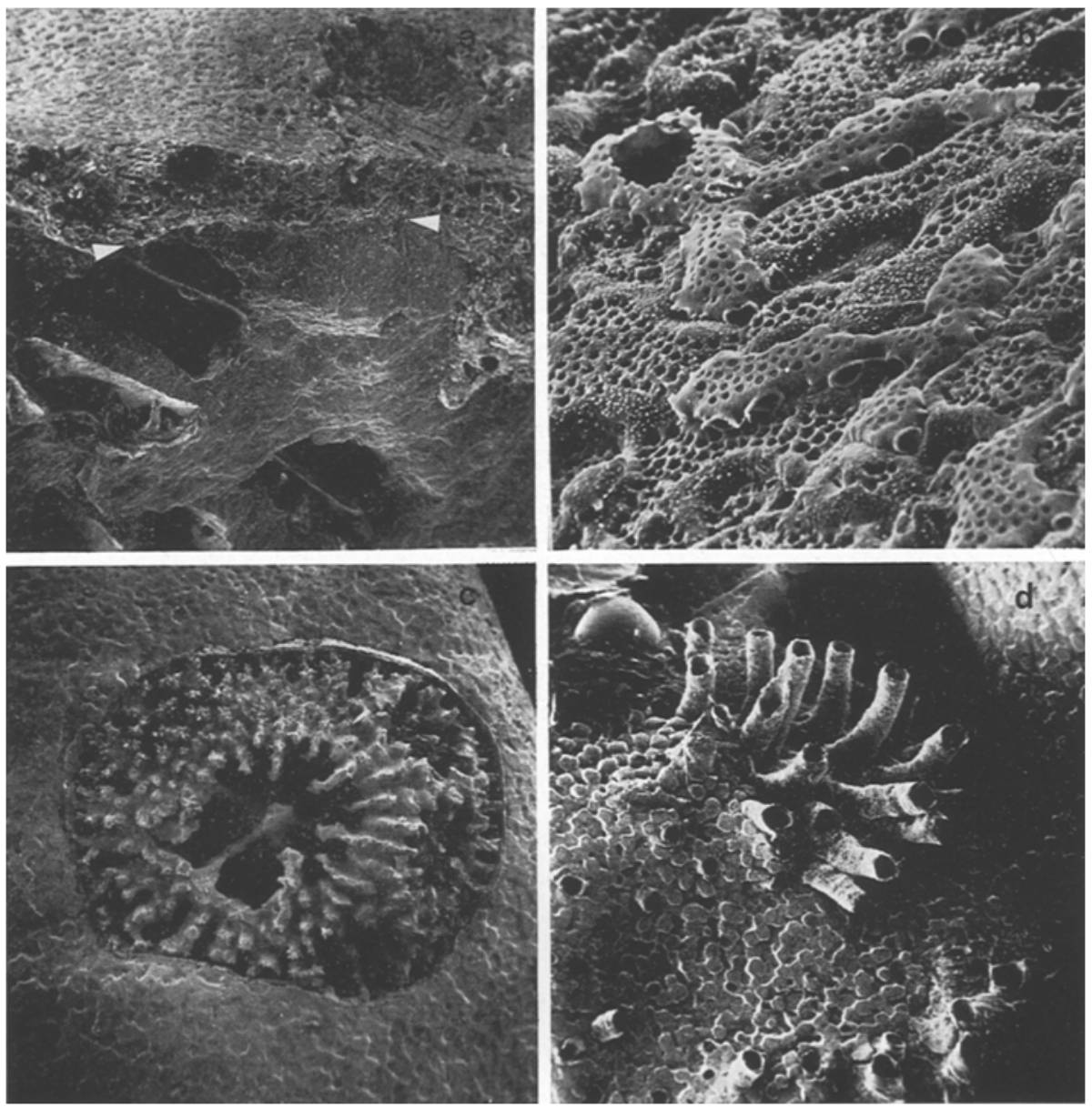

Fig. 6: Aspects of frame binding by subsequent encrustations of foraminiferans on a dead Pocillopora skeleton (SEM photographs): a vertical section showing a $200 \mu \mathrm{m}$ thick layer of acervulinid foraminiferans on the coral skeleton (arrows point at the border), $33 \mathrm{x} ; b$ surface of a Acervulina inbaerens layer (Acervulinidae) partially overgrown by Planorbulinoides retinaculata (?) (Cibicididae), $190 \mathrm{x}$; $c$ young Pocillopora colony, 1 to 2 weeks after planula settling, competing for space with encrusting foraminiferans, $30 \mathrm{x} ; d$ colony of calcareous bryozoans overgrown by acervulinid or planorbulinid foraminiferans, $19 \mathrm{x}$

not big enough to provide a suitable substratum. Foraminiferans and algae were the principal organisms encrusting the skeletons within a few months. Their layers attained a thickness of $2 \mathrm{~mm}$ within 2 years. A lot of other sessile and motile species colonized the dead skeletons. In Figure 5, the community associated with a living colony of Pocillopora danae is compared to the community on an equally sized skeleton. Eight species are associated with the living coral, 42 species with its dead counterpart.

Death of the coral induces a complete change in the composition of associated organisms. While the coral is alive, the community is mainly recruited from specificly 
adapted crustaceans and molluscs; after its death, the associated community is comprised of a much more diverse assemblage of organisms exhibiting less specialized adaptations (Fig. 5). Following death of the coral tissue, the calcareous matter continues to increase, however, not by contributions of coral polyps but by other lime secreting organisms (Figs $3 \mathrm{~h}, 6$ ). On a Pocillopora example, 2 years after tissue death, the layers formed by calcareous algae, foraminiferans and bryozoans represented four $\%$ of the total weight and also four $\%$ of the volume of the specimen (Table 1). Exposure to light and water movement influences the development of these subsequent coatings: the upper sides of the colony, directed to the open water, were covered with layers up to $2 \mathrm{~mm}$ thick, whereas the sides facing the substratum were barely coated. Massive corals, which exhibit less surface area than branching forms of comparable age, were not coated to the same extent, probably, since they do not extend into the water to the same degree as branching forms (Table 1).

Table 1

Calcareous substance, colonization-space and community represented by live and dead colonies of Pocillopora danae and Favia laxa (6 or 5 years old)

\begin{tabular}{|c|c|c|c|c|c|c|c|}
\hline Species & Growthform & $\begin{array}{c}\text { Dim } \\
\text { height } \\
\text { (cm) }\end{array}$ & $\begin{array}{l}\text { nsions } \\
\text { width } \\
\text { (cm) }\end{array}$ & $\begin{array}{l}\text { Area covered } \\
\text { by the } \\
\text { colony }\left(\mathrm{cm}^{2}\right)\end{array}$ & \multicolumn{2}{|c|}{$\begin{array}{l}\text { Weight } \\
(\mathrm{g})\end{array}$} & $\begin{array}{l}\text { Volume } \\
\left(\mathrm{cm}^{3}\right)\end{array}$ \\
\hline $\begin{array}{l}\text { Pocillopora } \\
\text { danae }\end{array}$ & branched & 14 & $16 \times 22$ & 14 & \multicolumn{2}{|c|}{510} & 270 \\
\hline Favia laxa & spherical & 4,5 & $3 \times 8,5$ & 51 & \multicolumn{2}{|c|}{157} & 133 \\
\hline Species & $\begin{array}{l}\text { Surface } \\
\left(\mathrm{cm}^{2}\right)\end{array}$ & \multicolumn{2}{|c|}{$\begin{array}{l}\text { Colony portion made } \\
\text { of secondary } \\
\text { encrustations } \\
\text { weight } \\
\begin{array}{ll}\text { (g) } & \left(\mathrm{cm}^{3}\right)\end{array}\end{array}$} & \multicolumn{2}{|c|}{$\begin{array}{l}\text { Number of species } \\
\text { settling on the } \\
\text { colony } 2 \text { years after } \\
\text { death }\end{array}$} & \multicolumn{2}{|c|}{$\begin{array}{c}\text { Number of species } \\
\text { settling on a } \\
\text { comparable living } \\
\text { colony }\end{array}$} \\
\hline $\begin{array}{l}\text { Pocillopora } \\
\text { danae } \\
\text { Favia laxa }\end{array}$ & $\begin{array}{l}480 \\
100\end{array}$ & $\begin{array}{r}18 \\
1\end{array}$ & $\begin{array}{l}10 \\
0,5\end{array}$ & $\begin{array}{l}42 \\
12\end{array}$ & & & $\begin{array}{l}8 \\
4\end{array}$ \\
\hline
\end{tabular}

Artificial reefs have been studied in regard to their attractiveness for fishes (e.g. Randall, 1963). The investigations at the embankments of Eilat concerned both the increase in fish population synchronously with the development of the benthic community. Beginning with a few species, more than 70 fish species became regular visitors or residents at the GBH. An analysis of the fish community or its fluctuations is in preparation.

\section{DISCUSSION}

For 200 years, man-made structures on the seabed have served as "artificial reefs" improving the coastal-fishery output (Ino, 1974). The reef examples dealt with in this paper create a semantic problem. Most of those structures used in fish management do 


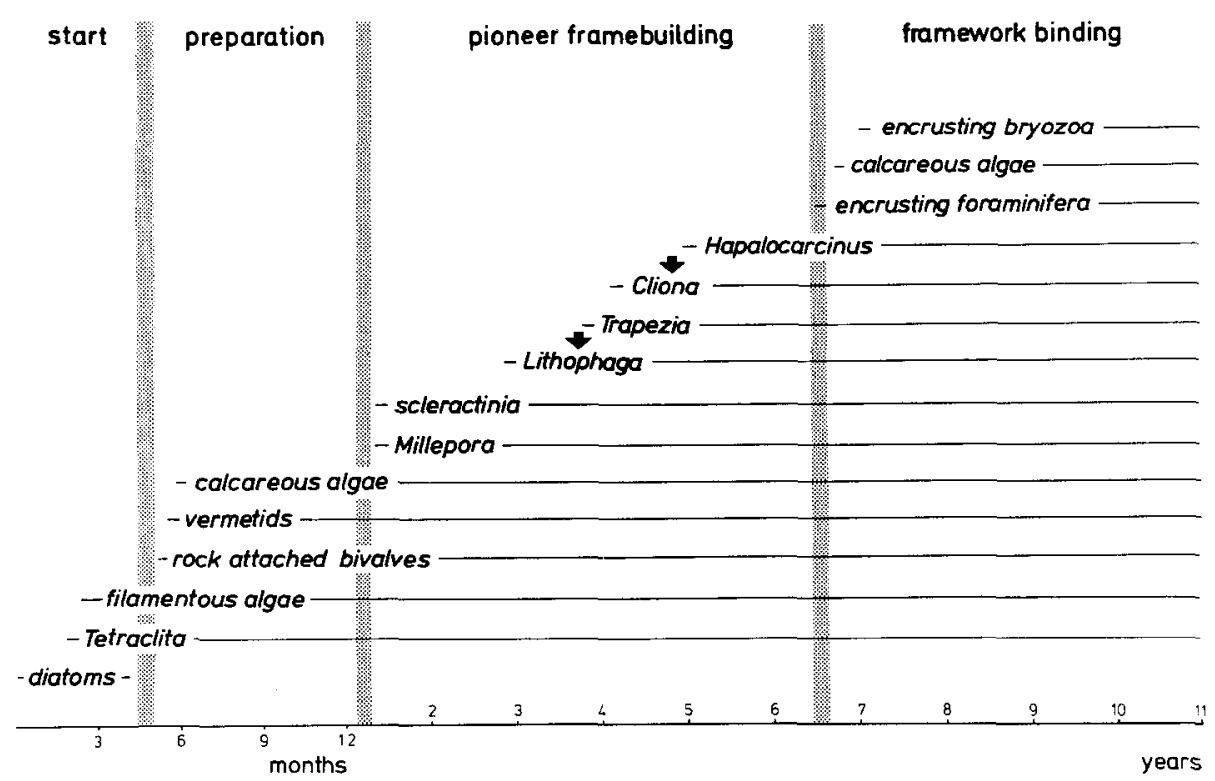

Fig. 7: Successive colonization of artificial reef types thus far classified in four phases of reef development; the arrows point at coral and reef destructing agents

not conform to the term "reef" in the proper sense, since they typically do not extend to the surface layers of the sea. On the other hand, it is well known that a situation in shallow water is prerequisite for coral reef development (e.g. Schuhmacher, 1976), Hence the present embankments can much more be regarded as "artificial reefs" than other artificial habitats such as the mentioned constructions used in fish management.

Geologists (Ginsburg \& Lowenstam, 1958; Schroeder \& Zankl, 1974) distinguish four mechanisms which must interact for the formation of a reef structure: framebuilding and -binding, cementation of pores, and filling by sediments. In established reefs these processes operate simultaneously and continuously. The observation of a developing reef community reveals how the processes become sequentially effective being integrated in an even more extensive succession of the whole community (Fig. 7).

Before any framework is established certain preliminary events seem to determine the distribution pattern of future frame builders. Usually, a virgin (unpopulated) substratum is at first colonized homogeneously by fouling organisms. This $5 \mathrm{t}$ a $\mathrm{rt}$ phase, not yet immediately affecting the final reef development, is followed by a preparation-phase, during which grazing animals consume the new growths of first settlers. Early settled barnacles, shells and calcareous red algae are not grazed because of their resistent tests. These tests provide a foothold for subsequently settling larvae, resulting in disjunct distribution patterns. Examination of the base of coral colonies showed that, in most cases, these were attached to other calcareous material and not directly to the granite of the boulders or the asbestos test panels. The relative importance in site choice of chemotaxis versus rugotaxis remains to be determined. 
The scleractinian Stylopbora pistillata was abundant among the pioneer frame builders being an opportunistic species (Loya, 1976). In addition, my observations indicate that Pocillopora and certain massive corals exhibit the same strategy. Stony corals and hydrocorals continue to produce a disjunct pattern which becomes the $\mathrm{p}$ ion e r f ramework of the reef. The framework attracts additional reef benthos in the new shelter evolving into numerous proto-reef communities. Among these assemblages certain organisms, for example Tridacna, continue the frame-building processes as secondary frame builders.

The usually high mortality rate among young scleractinians (Connell, 1973) provides enormous additional colonization sites. A Pocillopora colony which died after 6 years of growth occupied a base area of $14 \mathrm{~cm}^{2}$ and had a skeleton surface of $480 \mathrm{~cm}^{2}$ available for settlement (Table 1). A dead coral colony harbours an abundant variety of species, resulting in a higher species diversity compared with the few specialized organisms adapted to life in and on living coral tissue. This fact explains the high species diversity in "dead reef parts" (Mergner \& Schuhmacher, 1974).

As contrasted to frame-building discussed above, the encrusting forms, especially homotrematid and acervulinid foraminiferans, contribute most substantially to the strengthening layers covering the coral frame. Their activities characterize the $\mathrm{p} \mathrm{h}$ a s e of $\mathrm{frame-binding.} \mathrm{The} \mathrm{role} \mathrm{of} \mathrm{the} \mathrm{encrusting} \mathrm{foraminiferans} \mathrm{is} \mathrm{emphasized,}$ whereas bryozoans, which are considered as important frame binders (Cuffey, 1972; Soule \& Soule, 1974), are more scarce, and restricted to areas with minimal water circulation. Calcareous algae, especially Porolithon sp., are mainly restricted to surfexposed regions.

The two remaining mechanisms essential for reef formation, cementation and sedimentation, become effective later in reef development, when more coralline material is accumulated than presently available at the artificial reefs. Thus Friedman et al. (1974) showed that the degree of cementation is not yet considerable before some $\mathrm{cm}$ below the surface of an already established coral reef. The process of spacefilling by sediments requires amounts of loose material not yet produced, too, at the investigated sites.

Borers are among the pioneers successfully colonizing the living coralline tissue. Before the surface of the coral provides proper shelter for epibionts, several Litbophaga species may penetrate into the live skeleton (Gohar \& Soliman, 1963). They, in turn, enable boring sponges (Cliona spp.) to invade - even though normally they do not infest living corals. Hence, bio-erosion and -corrosion (Schneider, 1973) limit coral reef formation from its very beginning.

Acknowledgement. I am indebted to the staff of the "Heinz Steinitz Marine Biology Laboratory" at Eilat for kind assistance during several stays. Dr. G. Bijvank (Ruhr-Universität Bochum, FRG) operated the SEM. The field work was financially supported by the Deutsche Forschungsgemeinschaft. 


\section{LITERATURE CITED}

Connell, J. H., 1973. Population ecology of reef-building corals. In: Biology and geology of coral reefs. Ed. by O. A. Jones \& R. Endean. Acad. Press, New York, 2, 205-246.

Cuffey, R. J., 1972. The roles of bryozoans in modern coral reefs. Geol. Rdsch. 61, 542-550.

Friedman, G. M., Amiel, A. J. \& Schneidermann, N., 1974. Submarine cementation in reefs: example from the Red Sea. J. sedim. Petrol. 44, 816-825.

Ginsburg, R. N. \& Lowenstam, H. A., 1958. The influence of marine bottom communities on the depositional environment of sediments. J. Geol. 66, 310-318.

Gohar, H. A. F. \& Soliman, G. N., 1963. On three mytilid species boring in living corals. Publs. mar. biol. Stn Ghardaqa 12, 1-98.

Grigg, R. W. \& Maragos, J. E., 1974. Recolonization of hermatypic corals on submerged lava flows in Hawaii. Ecology 55, 387-395.

Ino, T., 1974. Historical review of artificial reef activities in Japan. In: Proceedings of the artificial reef conference. Ed. by L. Colunga \& R. Stone. Texas A \& M Univ., Houston, 21-23.

Loya, Y., 1976. The Red Sea coral Stylophora pistillata is an $\mathrm{r}$ strategist. Nature, Lond. 259, $478-480$.

Mergner, H. \& Schuhmacher, H., 1974. Morphologie, Okologie und Zonierung von Korallenriffen bei Aqaba (Golf von Aqaba, Rotes Meer). Helgoländer wiss. Meeresunters. 26, 238-358.

Potts, F. A., 1915. Hapalocarcinus, the gall-forming crab, with some notes on the related genus Cryptochirus. Pap. Dep. mar. biol. Carnegie Instn Wash. 8, 35-71.

Randall, J. E., 1963. An analysis of the fish populations of artificial and natural reefs in the Virgin Islands. Caribb. J. Sci. 3, 31-47.

Schneider, J., 1973. Biologische und anorganische Faktoren beim Abbau einer Kalkküste. Habil. Schr., Univ. Göttingen, 329 pp.

Schroeder, J. H. \& Zankl, H., 1974. Dynamic reef formation: a sedimentological concept based on studies of recent Bermuda and Bahama reefs. Proceedings of the 2 nd international coral reefs symposium Great Barrier Reef Comm., Brisbane, 2, 413-428.

Schuhmacher, H., 1973. Die lichtabhängige Besiedlung von Hafenstützpfeilern durch sessile Tiere und Algen aus dem Korallenriff bei Eilat (Rotes Meer). Helgoländer wiss. Meeresunters. 24, 307-326.

- 1974. On the conditions accompanying the first settlement of corals on artificial reefs with special reference to the influence of grazing sea urchins (Eilat, Red Sea). In: Proceedings of the 2nd international coral reefs symposium Great Barrier Reef Comm., Brisbane, 1, 257-267.

- 1976. Korallenriffe. BLV, München, 275 pp.

Soule, J. D. \& Soule, D. F., 1974. The bryozoan-coral interface on coral and coral reefs. In: Proceedings of the 2nd international coral reefs symposium Great Barrier Reef Comm., Brisbane, 1, 335-340.

Author's address: Dr. H. Schuhmacher

Ruhr-Universität Bochum

Lehrstuhl für Spezielle Zoologie

Postfach 102148

D-4630 Bochum

FRG 